\title{
Litterær kvalitet, den litterære institution og den litterare kanon
}

\section{Af Claus Secher}

\section{Hvad er kunstnerisk kvalitet?}

Det vil være naturligt først at stille spørgsmålet: kan man overhovedet definere hvad der er kvalitet? Er det ikke bare et rent subjektivt begreb? "Smag og behag er forskelligt" - som man siger, og som mange sikkert mener. Men det gør ikke synspunktet rigtigere.

Når det for mig er helt oplagt at sige, at f.eks. litterær kvalitet eksisterer, er det bl.a., fordi jeg ikke er alene om at mene, at Shakespeare er den største dramatiker, der har levet. Man kan på flere forskellige niveauer argumentere for at Shakespeare er stor/den største. Man kan efter behag i argumentation tage udgangspunkt i retorikken, det vidunderligt musikalske sprog, det enormt alsidige ordforråd, eller i hans mageløse psykologiske karaktertegning eller fremhæve de dybt eksistentielle temaer i hans dramaer: liv og død, kærlighed, tvivl eller handling, magt eller afmagt. Inden for andre kunstarter kan man på tilsvarende vis sagligt argumentere for at Mozart, Rembrandt, Chaplin etc. var de største eller blandt de største. Noget der således kan argumenteres sagligt for, er ikke bare udtryk for en subjektiv dom.

På den anden side er en kvalitetsdom heller ikke objektiv i den forstand, at den kan bevises. Det er der nu ikke ret meget der kan, heller ikke mange naturlove. Videnskab arbejder i højere grad end med beviser med frugtbare hypoteser. At operere med en påstand om at Shakespeare er "en døgnflue" er ikke særlig frugtbart, hvis han næsten 400 år efter sin $\mathrm{d} \varnothing \mathrm{d}$ stadig spilles for fulde huse over hele verden.

Det betyder naturligvis ikke, at de forskellige kunstarter har et uforanderligt hierarki af kunstnere, som regnes for de store, og at kvalitetsbegrebet er evigt og aldrig undergår historiske forandringer. Man er ikke for tid og evighed sikret en plads på parnasset, historien står altid til diskussion, og historiske forandringer i sprog, foretrukne genrer og forestillinger om hvad der er relevant eller oplevelsesværdigt skifter. Alligevel er det ofte bemærkelsesværdigt hvordan nogle værker eller kunstnere overlever i meget lange perioder. Det er svært at forestille sig teatre uden Shakespeare, men det er selvfølgelig historisk set en mulighed. Nye fremragende oversættelser af Homer, Vergil, Ovid eller Dante kan pludselig gøre klassikerne aktuelle igen.

Overlevelse i kvalitativ forstand hænger sammen med at nogle mennesker stadig begejstres over de gamle digtere. Disse begejstrede mennesker kan f.eks. være: oversættere, sceneinstruktører eller teaterdirektører, filminstruktører og producere. De kan også være bibliotekarer, der formidler en personlig læseoplevelse til en låner. De begejstrede formidlere kan så håbe på, at de ikke står ale- 
ne med deres begejstring. Kunstarterne kan have forskellige historier og blomstringstider; vi får f.eks. først en større romanproduktion fra og med 1700-tallet, selv om man har mange romanlignende fortællinger eller eposer tidligere. Der er ikke så megen malerkunst fra før renæssancen, der er spændende og levende. Forældelsesgraden kan være forskellig inden for de forskellige kunstarter og medier. Vores samtid er generelt en brug og smid væk-kultur og præget af information overload, andre tidligere epoker har været langt mere statiske, på grund af langt færre kunstneriske informationer.

\section{Institutionsteorien}

Det, jeg hermed indledningsvis har fors $\emptyset \mathrm{gt}$ at indkredse er, hvad der i den filosofisk orienterede æstetik kaldes institutionsteorien. Den gør David Favrholdt oprør mod i AEstetik og filosofi: seks essays (2000), det vil jeg komme ind på om lidt. Positivt udfoldet finder man institutionsteorien hos Søren Kjørup i Kunstens filosofi - en indføring $i$ aestetik (2000), og i Ole Thyssens En moerkelig lyst - om iagttagelse af kunst (1998). En meget kraftig inspiration hos Thyssen er Niklas Luhmann og hans teori om autopoietiske systemer, som igen minder meget om Bourdieus feltbegreb. Begge begreber hænger sammen med udviklingen af det refleksive samfund og dets arbejdsdeling og dets mange udviklede ekspertsystemer.

I artiklen Litteratur och samhälle har den svenske litteratursociolog Lars Furuland en model over den litterære proces og institution.(1) I modellen over bogens vandring fra forfatter til læser anvender Furuland omkring distributionen af bogen begrebet "indplacering i værdisystem". Flere instanser i det litterære system er involveret i denne værdimæssige indplacering på både kortere og længere sigt. Litteratur møder både forskere, dagbladskritikere, bibliotekarer, lektører og boghandlere. Flere led i den litterære institution beskæftiger sig med værdisætning af bøger og giver de litterære værker ord og vurderinger med på vejen.

Institutionsteorien siger altså, at vurderinger genereres inden for et felt i den pågældende institution. Institutionen definerer hvad der er godt eller skidt, hvad der er kunst og hvad der ikke er det. Institutionen etablerer regler for vurdering og et sprog at udtrykke disse vurderinger i. De forskellige led i institutionen f.eks. forskere, undervisere, dagbladsanmeldere, lektører vurderer forskelligt ud fra deres placering. Universitetsfolk ligger $\emptyset$ verst i hierarkiet, dagbladskritikere i midten alt afhængigt af bladets profil, mens lektørerne er mere lydhøre over for det de opfatter som den mere folkelige, dvs. efterspurgte smag, og lavest i institutionens selvopfattelse kommer konsumenterne. Det kan ændre sig over tid. F.eks. er dagens kulturproduktion nok i endnu højere grad præget af konsumentvinklen end tidligere.

Man kan se det litterære hierarki i spil på mange andre måder, f.eks. anlægges der en mere salgsmæssig synsvinkel, når boghandlernes "gyldne laurbær" uddeles, mens Det danske Akademis pris eller Nordisk Råds litteraturpris uddeles efter rent æstetiske kriterier. Jane Aamund kunne aldrig få de to sidstnævnte priser. Polemikker mellem forfattere eller litterære skoler har ofte rødder i forfatternes placering i forskellige litterære delkulturer, som når f.eks. populære spændingsforfattere som Leif Davidsen og Michael Larsen polemiserer imod Forfatterskolen og dens påståede anæmiske, minimalistiske prosa. Den litterære institution og andre kunstinstitutioner er altså ikke uden modsætninger og undergår historiske forandringer.

En pointe hos Søren Kjørup i Kunstens filosofi en indføring $i$ cestetik i kapitlet om Vurdering er, at de kunstneriske institutioner skaber et sprog, hvorigennem samtaler om kunst føres,(2) og argumenter for vurderinger produceres. Disse institutionelle argumenter fungerer i Wittgensteins forstand som sprogspil, dvs. som argumenter der ikke opfattes som beviser, men netop som fornuftige argumenter, hvorudfra en diskurs inden for institutionen kan føres. Hvis jeg f.eks. mener, at Gabriel García Márquez' Hundrede års ensomhed er et mesterværk i det 20. århundredes litteratur, synes jeg det, fordi den fortæller en væsentlig historie, Columbias og Sydamerikas blodige og smertelige historie. Den er desuden mesterlig, fordi dens personer er levende og alsidige, velkendte men også $\mathrm{i}$ deres lidenskaber fremmedartede og eksotiske. Jeg kan lide romanens fornyende form, den magi- 
ske realisme, hvor historisk realisme og mere fantastiske og mytiske lag fra indianerkulturen smelter sammen. Romanen er både smertelig og meget humoristisk.

Kunst opleves umiddelbart, men diskussionen om den etableres via en lidt senere indtrædende refleksion, ligesom god kunst først produceres, sprænger tidligere rammer og først bagefter gøres til genstand for refleksion i f.eks. dagbladskritik, poetikker eller akademiske afhandlinger. Kvalitetsvurderinger er derfor ofte bagkloge i forhold til en forudgående oplevelse eller mangel på samme. Derfor oplever mange det at dissekere en tekst $\mathrm{i}$ en undervisningssituation som et overgreb mod oplevelsen og påstår, at de får ødelagt deres forhold til litteratur.

En anden pointe hos Kjørup er, at analyse og vurdering hører sammen og ikke - som f.eks. retningslinier for lektørudtalelser foreskriver - er adskilte funktioner. Den måde, hvorpå vi beskriver værket, er afgørende for, hvordan vi vurderer det. Som Kjørup skriver: "Hvis jeg siger om et kunstværk at det har en klar udvikling, en afrundet form, et stærkt følelsesudtryk, enhed i stil, mange interessante detaljer osv., samt hævder at det er kunstnerisk mislykket, så vil man sikkert fornemme, at jeg modsiger mig selv".(3) Analysen lægger allerede præmisserne for vurderingen, og det er den litterære institutions spilleregler, der bestemmer hvordan samtaler eller monologer som f.eks. anmeldelser genereres.

Institutionsteorien findes endnu mere udviklet i Ole Thyssens En moerkelig lyst-om iagtagelse af kunst. Thyssens inspirationskilder er Immanuel Kant, som han ser som den moderne æstetiks grundlægger og Niklas Luhmanns teori om de autopoietiske systemer, specielt som den med hensyn til kunstområdet er udfoldet i Die Kunst der Gesellschaft (1995). Kant udskilte i Kritik der Urteilskraft (1790) æstetikken eller læren om det skønne fra de områder, den tidligere havde været forbundet med: religionen, den videnskabelige fornuft, etikken og politikken, (ligesom Thyssen i 1993 skrev en bog om informationssamfundet, i 1995 en bog om etik og altså i 1998 om det æstetiske).
Kant koblede æstetikken sammen med den særlige følelse, som kunsten vækker i læseren, og ikke med fornuften, og betragtede kunstens rolle som at vække det interesseløse behag, frigjort fra etiske og politiske bindinger. Kant skelnede i sin æstetik mellem det skønne og det sublime. Det skønne fremkaldes af orden og symmetri i både natur og i det formelle i kunstværker, mens han forbinder det sublime med særligt stærke oplevelser i naturen, som kan være tætte på det religiøse og det rystende, gruopvækkende. Det sublime oplever mennesket f.eks. i forbindelse med et hav i oprør og et tordenvejr. Ved at henvise kunstens opgave til at vække følelser hos betragteren frigjorde Kant æstetikken fra dens tidligere bindinger, men når han skulle diskutere kvalitet og god smag, faldt han iflg. Thyssen tilbage til en henvisning til en fælles smag, som findes hos dannede individer.(4)

Kants æstetik ligger tidsmæssigt lige i overgangen mellem rationalisme og romantik, og med romantikken ser Thyssen kunsten frigøre sig fra den dannede smag og blive til det komplekse kunstsystem, vi kender i dag. Det sublime bliver i romantikkens litteratur til det gruopvækkende, f.eks. i den gotiske roman og den tyske romantiske novelle, eller til det hæsliges indtog i den realistiske eller den modernistiske kunst. Endelig er det også i det 19. århundrede, at kunstmarkedet, frigjort fra mæcenatet, udfolder sig med markerede grænser mellem fin og lav eller triviel kunst. Det betyder en markant ændring og relativering af normerne for det skønne og for kunsten. Ifølge Thyssen og Luhmann er det romantikkens sprængning af det klassiske skønhedsbegreb, vi stadig kulturelt lever under.

Med denne udvikling bliver det kunstsystemet, der afgør forskellen mellem kunst og ikke-kunst. Kunsten bliver, som Thyssen siger, "et domæne for institutionaliseret antiinstitutionel adfærd",(5) en paradoksal tankegang, der også lå bag Villy Sørensens tankegang i 1960'erne i forbindelse med Kunstfond-debatten, hvor han hævdede, at staten skulle st $\varnothing t t e$ den ofte samfundskritiske kunst i sin egen interesse.

Kunstsystemet lukker sig om sig selv, som autopoietiske systemer gør. Kunstsystemet er sig selv, 
men det står også i moderne tid i relation til markedet, undervisningssystemet, massemedierne og det politiske system, og debatten fra de systemer påvirker og indoptages i kunstsystemet. Helt nutidige fænomener som individualisering og globalisering påvirker det. Den romantiske relativisering af kunstnormerne fortsætter og skaber stadig st $\varnothing$ rre usikkerhed om, hvad der er godt, og hvad der er skidt. Traditioner er ikke evige, men består i en midlertidig stabilitet, indtil systemets selvrefleksivitet sprænger dem.

\section{Parameterteorien}

David Favrholdts bog Astetik og filosofi: seks essays præsenterer sig som et opgør imod institutionsteorien og sætter i stedet det, han kalder parameterteorien. Det, der tydeligt irriterer ham ved institutionsteorien, er udviklingen inden for billedkunsten i det 20. århundredes avantgardekunst begyndende med Marcel Duchamps readymades, f.eks. "Urinal" og Mona Lisa med hageskæg.(6) Provokationen for Favrholdt er, at kunstinstitutionen har anerkendt hele den avantgardistiske udvikling fra Duchamp og frem med konceptkunst, Fluxus, happenings etc. Udover denne udviklingslinie i billedkunsten omtales med hån John Cages komposition 4.33, som består af en pause, der varer 4 minutter og 33 sekunder, og Vagn Steens to digtsamlinger Riv selv og Skriv selv. Sidstnævnte bestod af lutter tomme sider, hvor læseren kunne skrive sine egne digte. Begge Steens bøger var baseret på et koncept, der fokuserede på læserens meddigtende og dermed (i hvert fald i teorien) demokratiske rolle.(7)

Måske kan man sige, at Cages musikalske happening og Steens tomme sider er relativt enestående inden for medierne musik og litteratur, fordi deres provokationsværdi hurtigt vil transformeres til ligegyldighed, mens provokationer i billedkunsten snarere er reglen end undtagelsen, idet den radikale fornyelse i høj grad er blevet et avantgardistisk institutionskriterium inden for den moderne kunst. Der går f. eks. en lige linie fra Duchamp over 1960'ernes happenings og Fluxus til nyere tids absolut meget diskuterede værker: Bjørn Nørgaards hesteslagtning, Piero Manzonis Merda d'artista, Christian Lemmerz' svinekroppe og sværddragerne i blenderen på Trapholt.
For Favrholdt bliver det en skandale, at kunstinstitutionen har indoptaget denne avantgarde/happening-tradition i sig uden - synes han - at argumentere ordentlig for, at det drejer sig om kunst. Det provokerende ved institutionsteorien er ifølge Favrholdt, at den egentlig bliver en magtteori, der argumenterer ved hjælp af en magtbærende cirkelslutning. Disse værker er god kunst, fordi vi haevder, de er det.

I stedet sætter Favrholdt så sin parameterteori, der hævder, at man kan vurdere kunstens kvaliteter ud fra en række almene parametre. Disse parametre er a) integration (enhed), b) mangfoldighed eller kompleksitet, c) teknisk kunnen, d) æstetisk skønne kvaliteter, e) personpræg, f) gentagelighed, g) intellektuel appeal, h) emotionel appeal, i) andre suggestive kvaliteter (f.eks. integrationen af hæslige elementer i en kunstnerisk helhed), j) det uudsigelige budskab (værkets metafysik). Til de forskellige kunstarter kan der knytte sig en række underparametre: godt plot til litteraturen, intensitet og teknik til ballet etc. Favrholdt nævner også en række forhold, der ikke er parametre: 1) værkets nyhedsværdi, 2) historien bag værket, 3) kunstværkets pris eller alder, 4) værkets politiske budskab, 5) et evt. religiøst budskab, 6) at værket har dannet skole. Disse forhold kan være interessante for kunsthistorien, men ikke for vurderingen af værket.(8)

Parameterteorien fors $\emptyset$ ger at være objektiv, videnskabelig og almen. Hvis de ti parametre som det sker i Favrholdts bog - appliceres på otte danske værker fra Vilhelm Lundstrøm til Claus Carstensen giver det med anvendelsen af en karakterskal på 1-10 for hvert parameter en række talkarakterer, der entydigt demonstrerer, at det moderne/modernistiske maleri i Danmark er (stor) kunst, mens happeningtraditionen med bl.a. Manzonis Merda d'artista (kunstnerens egen lort på dåse) absolut ikke er kunst.(9)

Favrholdt har det til fælles med institutionsteorien, at han mener, kvalitetsvurdering bygger på kulturelle kompetencer, som opstår gradvist og successivt i et menneskes liv, ved at det til stadighed udsætter sig for mødet med kunst. Herved skabes en forståelse for kunstens koder. For Favrholdt ligger kvaliteten i værkerne, selv om det 
kræver kulturelle kompetencer at afkode dem. For institutionsteorien, f.eks. Kjørup og Thyssen, foregår værditilskrivningen i kunstinstitutionen gennem forskning, anmeldelser og stadige diskussioner. Med Anthony Giddens' begreb kan man sige, at kvaliteten ligger i institutionernes stadige selvrefleksivitet.

Hvad Favrholdt angriber i institutionsteorien er det, man kunne kalde institutionens magtbrynde, hvor man uden æstetisk argumentation ophøjer værker, der muligvis udmærker sig ved provokatorisk fornyelse, men ikke ved teknisk kunnen. Han afviger derfor logisk nok fra kunstinstitutionen ved ikke at ophøje fornyelseskriteriet eller provokationen som æstetisk kriterium, mens han selv sætter teknisk kunnen - altså håndværksmæssige kvalifikationer - som et mere traditionelt parameter.

Favrholdts argumentation kan man være enig eller uenig i. Han har nogle fornuftige sociologiske betragtninger over, at provokationskunsten egentlig ikke - som hævdet i avantgardeteorierne - provokerer borgerskabet, men snarere folket eller mere præcist de lavere sociale lag, som kunstnere i teorien ellers solidariserer sig med, jf. f.eks. Rindal-debatten.

Min væsentligste anke mod Favrholdts bog er imidlertid hans påstand $\mathrm{om}$, at parameterteorien er et alternativ til institutionsteorien. Jeg mener, at hele Favrholdts argumentation for parametre og forestillingen om kulturelle kompetencer er en del af institutionsteorien. Favrholdt k $\varnothing$ ber faktisk meget af institutionsteorien; han er blot ikke villig til at anerkende en avantgardetradition, som kunstinstitutionen ellers anerkender, mens han med sin mere konservative filosofisk-æstetiske diskurs er mere end villig til at anerkende andre dele af institutionen, f.eks. maleritraditionen fra impressionisterne og frem til det abstrakte maleri, f.eks. Pablo Picasso.

Jeg synes oplagt også, at Favrholdt med sine parametre søger at objektivere normer, som i institutionsteorien mere er frugtbare begreber i en æstetisk diskurs end objektive sandheder. Intellektuel appel (ofte frem for emotionel appeal) vil f. eks. være et centralt vurderingskriterium i forbindelse med happenings/konceptkunst. Hvis man finder intellektuel appeal i konceptkunsten, vil man således med Favrholdts parameter nå til en helt anden positiv karaktergivning af de vurderede værker.

I sin fremstilling af institutionsteoriens vurderingskriterier fremhæver Søren Kjørup "enhed i mangfoldigheden" som det væsentligste kriterium i den generelle kunstinstitution fra klassicismen i 1700-tallet (Baumgarten og Kant) og frem til vore dage. Det svarer til Favrholdts to første kriterier: integration og mangfoldighed. Kjørup påstår, at de er en generel konstans i kunstinstitutionernes æstetik, selv om de måske yderlige skal præciseres som "stor enhed i en stor mangfoldighed". De historiske variationer, som så indtræder, når talen om kunst bliver mere moralsk eller mere politisk, forklarer han med, at i forskellige perioder blander den etiske debat, som foregår i andre institutioner, sig i den æstetiske debat, eller i politiserede perioder blander den politiske diskurs sig.(10)

Man kunne som eksempel nævne de problemer, amerikanske kritikere havde med de banebrydende lyrikere Ezra Pound og T. S. Eliot, hvis modernistiske stil de beundrede, men hvis fascistiske eller meget konservative politiske synspunkter de tog afstand fra. Forfattere som Céline og Knut Hamsun, der mere end flirtede med nazismen, har trods deres værkers æstetiske kvaliteter også været svære at sluge $\mathrm{i}$ hvert fald for samtiden og den umiddelbare eftertid. Fra en anden del af det politiske spekter kan man nævne faldet $\mathrm{i}$ interessen for lyrikeren og specielt dramatikeren Bertolt Brecht i de senere år efter Murens fald, selv om f.eks. Lars von Triers mesterværk Dogville har hentet megen inspiration i Brechts Verfremdungsteknik.

\section{Folkebibliotekerne, kvalitetsbegrebet og kultur- formidlingen}

Hvor kommer bibliotekerne og andre kulturformidlende institutioner ind i denne kvalitetsdebat, som hidtil har været beskrevet i rent filosofiskæstetiske tankegange? Det gør de kulturformidlende institutioner selvfølgelig i en kulturpolitisk sammenhæng. Bibliotekerne gør det via bibliotekslovens formålsparagraf om at "fremme oplysning, uddannelse og kulturel aktivitet ved at stille 
bøger og andet egnet materiale vederlagsfrit til rådighed" (paragraf 1) samt paragraf 3: "Folkebibliotekernes formål skal opfyldes gennem kvalitet, alsidighed og aktualitet i udvalget af det materiale, der stilles til rådighed".

Man bør bemærke, at bibliotekernes udvælgelse på baggrund af kvalitet er sekundær i forhold til de forskellige kunstinstitutioner. Den er kun yderst sjældent baseret på læsning af bøger, aflytning af cd'er eller gennemsyn af dvd'er, men baseres på de led i kunstinstitutionerne, som udgøres af dagbladsanmeldelser, i mindre grad akademisk kritik i tidsskrifter, og lektørudtalelser. Hertil kommer afvejningen af kvalitet i forhold til de to andre kriterier, alsidighed og aktualitet, hvor det i hvert fald i forhold til skønlitteratur primært er aktualitetssynsvinklen, der spiller en væsentlig rolle. Aktualitet varetages i den sammenhæng ofte ud fra genrevalg, medievakt interesse for et forfatterskab og udlånserfaringer med det pågældende forfatterskab. En ny roman af Ib Michael vækker større opmærksomhed og er dermed mere aktuel end en ny digtsamling af Simon Grotrian.

Bibliotekernes placering $\mathrm{i}$ det litterære system betyder, at konsumentsynsvinklen, de empiriske erfaringer med lånernes forbrug, kan vægtes højere end den mere æstetiske synsvinkel, der varetages i dagspressen. Det er desuden sådan, at jo mindre biblioteket er, jo mindre betyder dagbladsanmeldelser i forhold til lektørudtalelser. Lektørudtalelser er som bekendt meget korte anmeldelser, der skal fokusere på 1) beskrivelse af et værk, 2) personlig vurdering og 3) bedømmelse af værkets anvendelsesmuligheder $\mathrm{i}$ henholdsvis folke- og skolebiblioteker. Det sidste punkt vil influere på de to andre i den forstand, at en god bog for folkebibliotekarer også hyppigt vil være en bog, der kan bruges i udlånet.

Materialevalget er (endnu) decentralt, og folkebibliotekerne er kommunale institutioner. Også dette trækker i retning af at basere bogvalget i højere grad på aktualitet end på en abstrakt kvalitetsopfattelse, som med rette eller urette lokaliseres i en akademisk verden. Selvfølgelig er der mange eksempler på, at kvalitet og popularitet falder sammen, men generelt er det af de ovenfor skitserede grunde oplagt, at forventet efterspørg- sel bliver et dominerede parameter. Endelig er bibliotekerne indlejret i en almen kulturel udvikling, og også den peger i retning af en større vægtning af det populære, ligesom de tidligere skarpe grænser inden for de kunstneriske institutioner mellem høj- og lavkultur tenderer imod en postmoderne relativering eller tendentiel ophævelse af grænserne.

De norske sociologer Ivar Frønes og Ragnhild Brusdal taler i bogen På sporet af den nye tid om "kundesamfundet", og at vægten i samfundet har forskudt sig fra fokusering på produktion til fokus på konsumtion eller forbrug. Det moderne menneske møder også kulturverdenen i rollen som kunde, som et individ der kan vælge og vrage mellem forskellige tilbud på hylderne. I et kundesamfund svækkes respekten for autoriteterne, og den enkelte er mere tilbøjelig til at lade sin smag forme efter umiddelbare nydelsesmæssige behov frem for af, hvad ekspertlagene i institutionen dikterer. Kundesamfundet hører sammen med begrebet oplevelsessamfundet, og den kulturelle forbruger jager oplevelser snarere end erkendelse, selv om disse begreber selvfølgelig kan falde sammen. Kundesamfundet hører endvidere sammen med selvrefleksiviteten, hvor alle traditioner og autoriteter anfægtes.

Fra min egen unders $\varnothing$ gelse, Bibliotekernes og lånernes skønlittercere bogvalg (2000) vil jeg til belysning af hovedtendenser i det aktuelle sk $\varnothing$ nlitterære bogvalg nævne nogle af hovedkonklusionerne. Jeg er i undersøgelsen gået ud fra spørgsmålet om nationallitteraturer, hvor det f.eks. er meget tydeligt og ikke overraskende, at interessen for den udenlandske litteratur, hovedsageligt går i retning af den angelsaksiske, i mindre grad mod den skandinaviske og i meget ringe grad mod det udenlandske, der ligger uden for disse to store områder. Til gengæld er der stor interesse for nogle udvalgte populære danske forfatterskaber.

En anden væsentlig del af undersøgelsen angår bogvalgets relation til det litterære genrebegreb. Her er de markante tendenser, at romanen er langt mere populær end novelle, lyrik og dramatik, og at genrelitteraturen er enormt efterspurgt; det gælder krimier, spændingslitteratur, gysere og historiske romaner. Kærlighedsromanen (roman- 
ce) er også efterspurgt, men det er her, hvor den litterære institutions normer sætter sig gennem. Der er mange eksempler på fravalg af romance (manglende kvalitet), og blandt de tre undersøgte biblioteker fravælger biblioteket $\mathrm{i}$ forstaden Albertslund flere end de to i provinsen, Ringsted og Thisted. Til gengæld satser Albertslund mere på spændingsgenrerne end de to provinsbiblioteker.

Endelig så jeg også på forfatternes køn, fordi det var tydeligt, at velkøbte og -udlånte romaner ofte var angelsaksiske og danske kvinderomaner. Det afspejlede både bibliotekarernes og lånernes smag og alder. Den typiske skønlitterære låner synes ud fra kortlægningen af bibliotekar- og lånersmag at være: en 50-årig kvinde med lang eller mellemlang uddannelse.

Populærlitteraturens og specielt spændingslitteraturens efterspørgsel blandt lånerne, som i høj grad hænger sammen med den samme genrefiktions popularitet i de visuelle medier, kan belyses gennem den tyske sociolog Gerhard Schultzes tanker i Die Erlebnisgesellschaft (1992).(11) Schultze opererer med, at vi i 1950'erne levede i en kulturel knaphedsøkonomi med et smalt finkulturelt lag og et bredere folkeligt lag. 1960'erne og 1970'erne opfattes som en overgangsperiode med uddannelsesboom og større velstand, inden vi i 1980 'erne for fuld fart er inde i det, Schultze kalder oplevelsessamfundet. Oplevelsessamfundet er - som navnet siger - præget af søgen efter oplevelser (frem for erfaring) og forestillinger om umiddelbar behovstilfredsstillelse også på kulturområdet.

Fra 1980'erne og frem orienterer mennesker sig æstetisk i tre typer af "hverdagsæstetiske skemaer": 1) finkulturskemaet, 2) trivialskemaet, 3) spændingsskemaet. De tre skemaer svarer inden for romanen groft sagt til Franz Kafka, Jane Aamund og Stephen King eller inden for dramaet til Ibsen, soapopera og Rejseholdet. De hverdagsæstetiske skemaer kan ses i relation til alder og uddannelse og grupperes i forhold til forskellige livsstilsmiljøer, hvor specielt de yngre generationer i deres kulturforbrug prioriterer selvrealisering og spænding i deres kulturforbrug, mens de ældre i højere grad deler sig mellem finkulturen og den mere harmonisøgende underholdning.
I sin meget spændende interviewundersøgelse af norske folkebibliotekarers sk $\varnothing$ nlitterære læsning, Mellom elite og publikum - littercer smak og litteraturformidling blandt bibliotekarer $i$ norske folkebibliotek (2002), skelner Jofrid Karner Smidt mellem tre forskellige læserprofiler blandt de norske folkebibliotekarer: 1) den populære læserprofil, 2) den eksperimentelle læserprofil og 3) den seriøse læserprofil.

Ved den populære læserprofil forstås en positiv holdning over for populærlitteratur, ved den eksperimentelle at man inkluderer den eksperimentelle litteratur både i sin læsning og sin formidling og ved den seriøse læserprofil, at man primært læser og formidler den psykologiske og realistiske roman, inklusiv 1970'ernes kvindelitteratur. Samtidig afgrænser man sig med den "seriøse læserprofil" tøvende over for den populære og relativt bestemt over for den eksperimentelle litteratur. Pointen i Karner Smidts undersøgelse er, at den seriøse læserprofil er den dominerende blandt norske bibliotekarer. Mænd orienterer sig generelt set lidt mere både imod den eksperimentelle og den populære skønlitteratur end kvinder, og yngre bibliotekarer er mere positive over for populærlitteratur.

Der er hos flere bibliotekarer en vis splittelse mellem hvad man selv kan lide, og hvad man formidler, men der er tale om en tydelig tendens hos norske bibliotekarer til at distancere sig fra "ekspertlagene" inden for den litterære institution. Min unders $\varnothing$ gelse siger indirekte det samme om danske bibliotekarer. Bibliotekarerne forvalter ikke kun kunstneriske kvaliteter, men også kulturpolitiske kvaliteter, og det kan være klogt at se kvalitetsbegrebet i mindst denne dobbelte kontekst.

Henrik Kaare Nielsen siger i Kritisk teori og samfundsanalyse (2001), at man kan tale om kvalitet både $\mathrm{i}$ en kunstnerisk og en kulturpolitisk kontekst. Kvalitet hører for kunstens vedkommende sammen med ekspertkonteksten, mens den kulturpolitiske kvalitet hører hjemme i en offentligheds-/deltagerkontekst, hvor bagvedliggende normer kan være almen dannelse, udvikling af borgerne $\mathrm{i}$ et demokratisk samfund eller individuel udvikling gennem kunstneriske oplevelser. Kvalitet i kulturpolitisk forstand er altså primært et 
pædagogisk ideal, en proces der sker i læseren eller tilskueren, og ikke primært en intern kvalitet i et værk.

\section{Kanon og kvalitet - et litteraturhistorisk eksempel}

Mens det er en generel tendens i den større litterære offentlighed, at eksperternes smag svækkes til fordel for en relativisme, der tillægger den enkelte læsers smag en større autoritet, så kan tendensen inden for det mere speciallitterære kredsl $\varnothing \mathrm{b}$ være en anden. Folkebibliotekernes litteraturformidling inkluderer selvfølgelig også klassikerne og den litterære kanon. De er på linie med museer og arkiver også 'memory institutions'. Men den egentlige stadigt foregående revurdering af kanon, og vurderingerne af hvilke litterære tekster der er værd at bevare i nuet, og hvilke der kan forsvinde ud i glemslens mørke, foregår i høj grad inden for litteraturhistorieskrivningen.

Denne kanonskabende funktion i det litteraturhistoriske miljø kan illustreres ved nogle betragtninger over ligheder og forskelle mellem de to seneste udgaver af Danske digtere i det 20. århundrede. Her tænkes på forholdet mellem 3. udgave af Danske digtere i det 20. århundrede, 1980-82, og den nye 4. udgave fra 2000-2002. 3. udgaven var redigeret af Torben Brostrøm og Mette Winge, dengang henholdsvis professor ved Danmarks Lærerhøjskole og fagleder ved Danmarks Biblioteksskole og begge dagbladskritikere, mens 4. udgaven er redigeret af Anne-Marie Mai, professor ved Syddansk Universitet og indtil for nylig formand for Litteraturrådet.

Der er mange forskelle mellem de to udgaver. Én af dem er, at 4. udgavens skribenter i højere grad ensidigt kommer fra universitetsverdenen, mens flere i 3. udgaven kom f.eks. fra Biblioteksskolen eller var rekrutteret blandt andre forfattere. 3. udgaven og dens forgængere lægger vægten på forfatterportrættet, 4. udgaven taler eksplicit om forfatterskabsportrættet, altså en delvis forskydning fra den biografiske metode til værklæsning. 3 . udgaven har flere tværgående oversigtartikler, f.eks. om mindre, ekspressionistiske lyrikere, hverdagsrealister fra 20'erne til 50'erne, og i det sidste bind: arbejderforfattere, fantaster, skriftdigtere og modelrealister, subkulturelle stemmer, trivialfor- fattere og børnebogsforfattere. 3. udgaven bunker ofte mindre forfattere to og to (f.eks. Hulda Lütken og Bodil Bech, der får hver sin artikel i 4. udgaven). 4. udgaven har ingen sådanne oversigtsartikler; til gengæld har den nogle meget fyldige efterskrifter i alle tre bind, alle af hovedredaktøren Anne-Marie Mai. De kan læses som decideret litteraturhistoriske oversigter, hvor 3. udgaven havde kortere indledningsartikler i hvert bind.

En naturlig forskel mellem to udgaver af et sådant værk er selektionen af forfattere. Eldre forfatterskaber, som har mistet betydning, glider ud, og nye forfattere kommer til. Sådan må det være. Ikke desto mindre er det interessant at se, hvem der glider ud af dette bud på en dansk litterær kanon, og hvem der forsøges føjet ind i den.

Hvis vi ser på hvilke forfattere, der havde selvstændige portrætter i 3. udgaven, men er gledet ud af 4. udgaven, så drejer det sig om (her ses bort fra forskellige principper for hvilke forfattere, der hører til det 20. århundrede): Knud Hjort $\varnothing$, Emma Gad, Gyrithe Lemche, Aase Hansen, Johannes Wulff, Erling Kristensen, Knuth Becker, Leck Fischer, Ingeborg Buhl, Allan Bock, Aage Dons, Børge Madsen, Willy-August Linnemann, Ove Abildgaard, Jørgen Nash, Erik Stinus, Ulla Ryum, Finn Methling, Ernst Bruun Olsen, Leif Petersen, Angelo Hjorth, Hans Lyngby Jepsen, Poul Ørum, Bent William Rasmussen, Henning Ipsen, Jette Drewsen, Ulrik Gräs, Dea Trier Mørch, Peter Ronild, Palle Fischer, Hans Mølbjerg og Svend Johansen.

Hvis vi derudover ser på hvilke forfattere, der i 4 . udgaven har fået selvstændige "forfatterskabsportrætter", mens de i hovedsagen var med i oversigtsartikler i 3. udgaven, så drejer det sig i bind $1 \mathrm{om}$ : Helge Rode, Emil Bønnelycke, Robert Storm Petersen, Harald Landt Momberg, Rudolf BrobyJohansen, Hulda Lütken, Bodil Bech og Tove Meyer. I bind 2 er de nye portrætter af: Jørgen Leth, Christian Skov, Gynther Hansen, Per Kirkeby og Johannes L. Madsen. I bind 3 eksploderer selvfølgelig de nytilkommende, men af lidt ældre forfattere, der har fået deres eget portræt i 4. udgaven er: Klaus Høeck, Peer Hultberg, Knud Sørensen, Henning Mortensen, Arthur Krasilnikoff, Asger Schnack, Rolf Gjedsted, Vita Andersen 
samt de overvejende børnelitterære forfattere Bjarne Reuter og Ole Lund Kirkegaard.

Jeg mener afgjort, der er en tendens i dette bud på en opstilling af en dansk litterær kanon i 4. udgaven af Danske digtere $i$ det 20. århundrede. Blandt de fravalgte er der en stor overvægt af realistiske prosaister, der var populære i deres samtid, men som formodes ikke at holde kunstnerisk i dag. Tre rene dramatikere er fravalgt (Finn Methling, Ernst Bruun Olsen og Leif Petersen) og tre lyrikere (Ove Abildgaard, Jørgen Nash og Erik Stinus). I forhold til udgivelsesmængden af storgenrerne er fravalget af lyrikere mindst. Det er også tydeligt, at begrebet kvindelitteratur opfattes anderledes i dag. Forfatterne fra- eller tilvælges ikke længere blot på grund af deres (kvinde)køn eller evt. sociale betydning i samtiden, men ud fra vurderet æstetisk kvalitet.

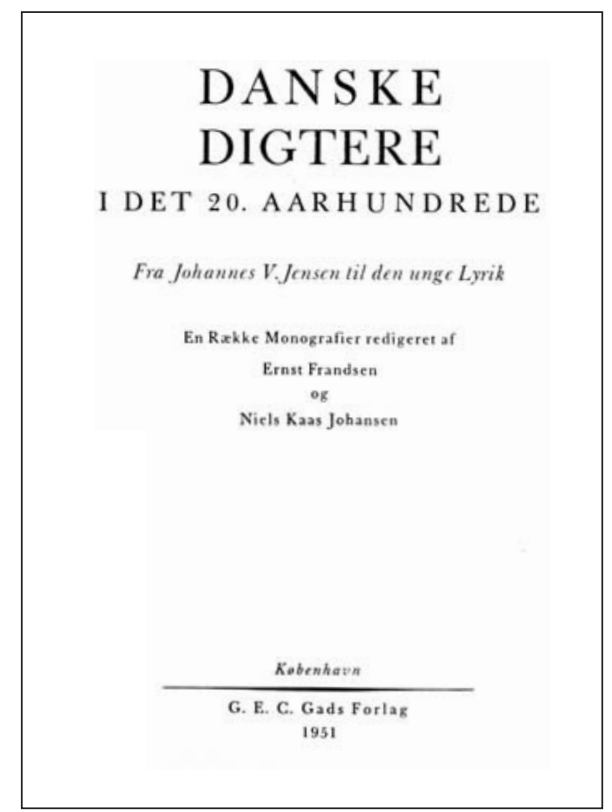

Det litteraturhistoriske forfattergalleri Danske digtere i det 20. århundrede udkom første gang i 1951; gennem tre senere starkt reviderede udgaver har skiftende redaktioner af dette standardvaerk forholdt sig til det blivende og det udskiftelige i den littercere kanon. Her titelblad fra 1. udgaven.

Hvis man ser på de tilkommende forfattere, er tendensen tydeligere. I bind 1 er de nye bortset fra det snurrige valg af Storm Petersen lutter lyrikere. Landt Momberg blev genopdaget af Poul Borum, hvis betydning for den litterære kanon i Danmark blandt yngre digtere og kritikere er enorm, men han har næppe fået mange nye læsere af den grund. Det samme kan siges om Broby-Johansen som lyriker. I bind 2 er to realistiske provinsforfattere samt tre lyrikere kommet til. Jørgen Leth og Per Kirkeby opfattedes i lidt ældre litteraturhistorieskrivning som "systemdigtere" (modernismens tredje fase), men peger i 4. udgaven frem mod det overordnede begreb "det formelle gennembrud" i 1970'erne.

Lyrikerne fylder også meget i bind 3. Når (overvejende) lyrikere som Asger Schnack, Rolf Gjedsted, T.S. Høeg, Morti Vizki, Simon Grotrian, Niels Lyngs $\emptyset$, og Lars Bukdahl er taget med, så må man i hvert fald sige, at lyrikken og avantgardedigtningen er generøst repræsenteret. Læser man "forfatterskabsportrættet" af Lars Bukdahl slår det én, at han ikke tillægges nogen særlig betydning som skønlitterær forfatter, men med rette som betydningsfuld yngre litteraturkritiker. Litteraturkritikere, der ikke er forfattere, er derimod ikke med i 4. udgaven, mens der var et fyldigt opsamlingskapitel om kritikere i 3. udgaven.

I 3. binds efterskrift i 4. udgaven - det først udkomne - lancerer hovedredaktøren Anne-Marie Mai begrebet "det formelle gennembrud" som hovedbetegnelsen for den nyere danske litteratur 1970-2000. I modsætning hertil ser hun hele perioden 1870-1970 som "det moderne gennembrud". (12) "Det formelle gennembrud" definerer hun som "at litteraturens karakter af at være form, dvs. et sprogligt og æstetisk mellemværende mellem den skrivende, den læsende og verden, tematiseres i teksten eller værket".(13) Hun beskriver det formelle gennembrud som et åbent felt og en "samtidighed mellem forskellige temaer, former og retninger i litteraturen".

Hun ser det formelle gennembrud begynde i 1960'ernes systemdigtning og forgrene sig både i eksperimenter med realismeformen i 1970'erne og i forskellige typer avantgardedigtning, og hun betragter det formelle gennembrud som et kunstnerisk udtryk for informationssamfundet og en $\emptyset$ get selvrefleksivitet hos digterne. Det formelle gennembrud ses også som et opg ør med spaltningen mellem høj- og lavkultur (populærkultur), jf. f. eks. Dan Turèlls og Svend Aage Madsens forfat- 
terskaber. Det er dog værd at påpege, at det der interesserer hovedredaktøren af værket ikke er populærkulturen - den er faktisk usynlig i de tre bind, men avantgardekulturens anvendelse af populærkulturens former og udtryk, det man også kunne kalde postmodernisme, der dermed tidsmæssigt forankres i en start allerede i 1960'erne, på et tidspunkt, hvor selve begrebet ikke har bredt sig til Europa.

"Det formelle gennembrud" er ikke bare nøglebegrebet for beskrivelsen af den nye litteratur i bind 3 , det får også betydning for vurderingen af traditionen, f.eks. i opvurderingen af Kirkebys og Jørgen Leths forfatterskaber (og deres beskæftigelse med populærkultur), for læsningen af Ivan Malinovskis lyriske forfatterskab og for portrættet af Dan Turèll. Opvurderingen i bind 1 af Landt Momberg og Broby-Johansen og af Storm P. som "seriøs" forfatter kan også ses i den sammenhæng.

Begrebet "Det formelle gennembrud" kan læses i tæt forbindelse med det, som Anne-Marie Mai, Jon Helt Haarder og Anne Borup, alle fra Syddansk Universitet, i en række artikler i tidsskriftet Kritik har kaldt opgøret med modernismekonstruktionen(14). Med "modernismekonstruktionen" sigtes til Torben Brostrøms betydningsfulde kritiske indsats i skabelsen af danskernes forståelse af den danske litterære modernisme. For Brostrøm er modernismen forbundet med en kritisk krisebevidsthed, en politisk kobling til kulturradikalismen og psykoanalysen og et litteraturpolitisk projekt der understregede den modernistiske litteraturs betydning for det moderne velfærdsstatsmenneske. I Brostrøms optik var modernismen også et opgør med den vestlige populærkultur. Heltene i Brostrøms litteraturhistoriske kanon var Villy Sørensen og Klaus Rifbjerg.

Over for Brostrøms modernismekonstruktion stiller Mai og de andre syddanske litterater samt Lars Bukdahl (en overgang poet in residence på Syddansk Universitet) en anden forestilling om "det åbne felt" med Peter Laugesen, Per Højholt og Dan Turèll som avantgardeskikkelserne med deres skriftbevidsthed, deres kollageagtige blanding af tekstformer, deres modstand mod den ophøjede lukkede tekst, samt deres hyppige brug af populærkulturelle citater.
Ikke alle artikler i Danske digtere $i$ det 20. århundredes 4. udgave forholder sig til denne skitserede tendens, men den slår igennem mange steder, f.eks. i portrætterne af Ivan Malinovski, Jørgen Leth og Peter Laugesen, samt i Lars Bukdahls forskellige artikler. Negativt slår den igennem i et meget ambivalent Villy Sørensen-portræt og et slattent Panduro-portræt på 5 sider, mens Per Højholt f.eks. får tildelt 17 sider.

\section{Kanon, kulturarv og det litterære felt}

Konkluderende kan man spørge, hvor stor en rolle for den litterære kanonformation og dermed danskernes litterære kulturarv, et værk som 4. udgaven af Danske digtere $i$ det 20. århundrede spiller? For det første skal man gøre sig klart, at denne kamp om litterære værdier foregår i et bestemt område af det litterære felt, nemlig universitetsverdenen og sandsynligvis også blandt forfatterne. Dette område er bestemt ikke uvæsentligt. Når man bliver skrevet ud af historien, betyder det meget, når man bliver skrevet ind, betyder det noget. Litteraturhistorieskrivningen og undervisningssystemet definerer til en vis grad brugen af ældre forfatteres værker eller manglen på samme. På den anden side kan ingen litterat gøre en forfatter folkekær, hvis læserne ikke vil være med, og den almindelige aktualitetsfiksering af læsningen af skønlitteratur i dag g $\varnothing \mathrm{r}$ et eventuelt folkeligt comeback yderst vanskeligt.

Universitetsområdet og forfatterpopulationen hænger til en vis grad sammen med litteraturkritikken. Lars Bukdahl er f.eks. indflydelsesrig som dagbladskritiker, og hans værdidomme, som de her er antydet, er altid til stede i hans anmeldelser. Jeg tror, at generationstilhørsforholdet spiller en stor rolle. Bukdahls status er langt højere blandt yngre forfattere og boglæsere end blandt ældre, for hvem en Torben Brostrøms eller en Erik Skyum-Nielsens æstetik spiller en langt større rolle. Endelig er der selvfølgelig litteraturlæsere af mere moden alder, hvis smag for længst er fastlagt, og som sjældent påvirkes af nye strømninger.

I sin på mange måder spændende bog $O g$ andre forfattere - dansk fiktionsprosa 1945-1960 (2001) peger litteraturforskeren Søren Schou på en række prosaforfattere i primært 1950'ernes danske lit- 
teratur, som gennem eksperimenter med novelleog romanform er med til at tegne en begyndende modernistisk dansk fiktion. Ingen af disse forfattere er i dag særligt kendte og læste. Unders øgelsen fokuserer på bl.a. Leif E. Christensen, Svend Aage Clausen, Finn Gerdes, Sonja Hauberg, Aksel Heltoft, Eiler Jørgensen, Hans-Jørgen Lembourn, Kelvin Lindemann, Guiseppe Scocozza og Jørgen Ulrich. Fælles for dem er, at de i roman- og novelleform eksperimenterer med en række modernistiske træk: krisebevidsthed, myte, legende og allegori, roman noir, satire, surrealisme, eksperimenterer med tid og rum. Derved introducerer de historisk modernismen i dansk fiktionsprosa.

Fælles for disse forfattere er - jf. deres ukendthed - at de ikke optræder i den hidtidige danske litteraturhistorie, og at 1950'erne derfor i denne hidtil har været beskrevet som ren Heretica-stemning, konservatisme, småborgerlig pænhed og den tavse generations periode. Her er det igen - om end i blidere form - Torben Brostrøms modernismekonstruktion, der gøres til forklaringen. Hos Torben Brostrøm begynder prosamodernismen i dansk litteratur med Villy Sørensen og Peter Seeberg, og selv om de faktisk debuterer i 1950'erne, så bliver modernismen hos Brostrøm og andre et 60 'er-fænomen, der markerer sig skarpt i et opg ør med 50'er-holdningernes konservatisme.

For Søren Schou er de genopdagede forfattere ikke alle oversete genier, men han synes, de fortjener opmærksomhed, og at det grå billede af 1950 'ernes litteratur bør revurderes. Schou har i slutkapitlet en overvejelse over den litterære kanons stabilitet, f.eks. i sammenligning med musikområdet, hvor komponister i langt højere grad udsættes for op- og nedture. Han nævner som eksempel opvurderingen af Gustav Mahler og nedvurderingen af Arnold Schönberg. Hans meget jordbundne og fornuftige forklaring er, at ændringer i den litterære kanon kræver langt mere læse-, forsknings- og skrivetid og psykiske kræfter, end de gør på musikområdet(15). Kanons relative konstans hænger også sammen med dens tætte relation til undervisningssystemet, hvor f.eks. gymnasiet reproducerer forskningens selektioner. Da et udvalg med Hans Hauge som formand i 1994 udsendte betænkningen Dansk litteraturs kanon - skønlitteratur i skolen, hæftede de sig bl.a. ved, at Danmark er et af de få europæiske lande, der ikke har en central litterær kanon for danskundervisningen i gymnasiet, men at eksamensopgivelserne fra landets mange lærere alligevel har en forbløffende ensartethed og konstans.

Betragtningerne over Danske digtere $i$ det 20. århundrede og forskellene mellem de to udgaver relaterer sig til brydninger i de dele af det litterære felt, som litteraturforskerne og til dels forfatterne forholder sig til. Strømningerne dér er væsentlige for hvilken kanon, der er aktuel og dermed også for hvilken litterær kulturarv, der gives videre. Begrebet "det formelle gennembrud" er et bud på et kvalitativt parameter, som ikke blot styrer udvælgelsen af nyere danske forfatterskaber, men som også peger bagud imod, hvordan den litterære arv (fra det foregående århundrede) forvaltes. Som alle kvalitetskriterier er det tendentiøst, f.eks. nedtoner det på en tvivlsom måde de formeksperimenter, som altid har foregået i den ældre litteratur, samtidig med at det i højere grad værdsætter avantgardistiske formeksperimenter end f.eks. samfundsmæssig relevans, således nedvurderingen af Leif Panduro, hvis tv-teater lagde de danske gader $\emptyset$ de, da de det blev sendt i monopolfjernsynets tidsalder.

Danske digtere i det 20. århundrede er et eksempel på, hvordan et bestemt delfelt inden for det litterære system kan agere. Her er værket blevet analyseret som et udtryk for et bestemt bud på, hvordan litterær kulturarv kan forvaltes. Andre bud inden for litteraturhistorieskrivningen er blevet givet og kan gives i fremtiden, og andre kvalitetskriterier eller parametre kan anvendes inden for den litterære institution. Det litterære felt består ikke kun af en universitær forskningsverden, men også af dagbladskritikere, undervisere på flere niveauer, forlagsfolk, boghandlere og bibliotekarer, ligesom forfattere kan producere for forskellige kredsløb inden for det litterære system. Selv om man kan sige, at den litterære kanon har en vis konservatisme indbygget i sig, er det litterære felt åbent og med mange brudflader. Min artikel har som helhed fors $\emptyset \mathrm{gt}$ at beskrive feltets åbenhed og de forskellige kvalitetsnormer, der kan knyttes til det. 


\section{Noter}

1. Lars Furuland: Litteratur och samhälle. I: Litteratursociologi, s. 206-207.

2. Se f.eks. Søren Kjørup: Kunstens filosofi, s. 190.

3. Søren Kjørup: Kunstens filosofi, s. 188.

4. Ole Thyssen: En moerkelig lyst, s. 37f.

5. Ole Thyssen: En markelig lyst, s. $266 f$.

6. Duchamp er helten i det kulturhistoriske rids i Per Højholts roman Auricula (2001), hvor provokationen, parodien og meningstømningen ses som karakteristika for den modernistiske avantgarde.

7. Jf. David Favrholdt: Astetik og filosofi, s.77.

8. Parameterteorien udfoldes af Favrholdt i 3. kapitel i Astetik og filosofi, s. 116-151.

9. Astetik og filosofi, s. 146-148.

10. Kunstens filosofi, s. $190 \mathrm{f}$.

11. Gengivelsen af Schultze bygger på Henrik Kaare Nielsens fremstilling i Kultur og modernitet, s. 139-150.

12. Jf. Danske Digtere i det 20. århundrede, 4. udg., bd. 1, s. 493.

13. Jf. Danske Digtere i det 20. århundrede, 4. udg., bd. 3 s. 510.

14. Opgøret med modernismekonstruktionen findes i følgende artikler: Anne-Marie Mai: The Thrill of it all, Kritik 137, Anne Borup: Den danske modernismekonstruktion, Kritik 147 og Jon Helt Haarder: Villy og Sørensen, Kritik 143. Jan Rosiek har i artiklen: Avantgardens genkomst? Selv en ny kanon kræver markante differentieringer, Kritik 152, forsvaret "modernismekonstruktionen".

15. Søren Schou: Og andre forfattere - dansk fiktionsprosa 1945-60, s. 201-205.

\section{Litteratur}

Borup, Anne (2000): Den danske modernismekonstruktion, Kritik, 147, s. 1-18
Dansk litteraturs kanon - skфnlitteraturen i skolen (1994). Kbh.: Undervisningsministeriet

Danske digtere $i$ det 20. århundrede. 3. udgave, bind 1-5 (1980-82). Red.: Torben Brostrøm og Mette Winge. Kbh.: Gads forlag

Danske digtere $i$ det 20. århundrede. 4. udgave, bind 1-3 (2000-2002). Red.: Anne-Marie Mai. Kbh.: Gads forlag

Favrholdt, David (2000): Astetik og filosofi: seks essays. Kbh.: Høst \& Søn

Frønes, Ivar og Ragnhild Brudal (2001): På sporet af den nye tid - kulturelle varsler for en noer fremtid. Kbh.: Gyldendal

Furuland, Lars (1995): Litteratur och samhälle. I: Litteratursociologi. En antologi redigeret af Erland Munch-Petersen, 2. udgave. Kbh.: Dansk Bibliotekscenter. s. 191-215

Haarder, Jon Helt (2000): Villy og Sørensen: skitse til læsning af et forfatterskab, Kritik, 143, s. 1-9

Karner Smidt, Jofrid (2002): Mellom elite og publikum - littercer smak og litteraturformidling blant bibliotekarer i norske folkebibliotek. Oslo: Det historiske fakultet, Universitetet i Oslo

Kaare Nielsen, Henrik (1993): Kultur og modernitet. Århus: Århus Universitetsforlag

Kaare Nielsen, Henrik (2001). Kritisk teori og samtidsanalyse. Århus: Århus Universitetsforlag

Mai, Anne-Marie (1998): The Thrill of it all. Kritik, 137, s. $46-56$

Rosiek, Jan (2001): Avantgardens genkomst? Selv en ny kanon kræver markante differentieringer. Kritik, 152, s. 30-38

Secher, Claus (2000): Bibliotekernes og lånernes skønlitterare bogvalg. Kbh.: Biblioteksstyrelsen Schou, Søren (2001): Og andre forfattere - dansk fiktionsprosa 1945-60. Frederiksberg: Roskilde Universitetsforlag

Thyssen, Ole (1998): En moerkelig lyst: om iagttagelse af kunst. Kbh.: Gyldendal. 